\author{
tukasz Jan Berezowski \\ Uniwersytet tódzki \\ lukasz.berezowski@uni.lodz.pl
}

\title{
TRUDNOŚCI W PRZEKŁADZIE WŁOSKICH LEKSEMÓW BEZEKWIWALENTOWYCH NA JĘZYK POLSKI NA PRZYKŁADZIE TERMINOLOGII KULINARNEJ
}

DOI: http://dx.doi.org/10.12775/RP.2020.002

\begin{abstract}
Zarys treści: Bogactwo terminologiczne języka włoskiego w najpopularniejszych obszarach życia (kuchnia, moda, muzyka etc.), a w szczególności zintensyfikowane kontakty włosko-polskie przełomu XX i XXI w. są przyczyną pojawienia się w polszczyźnie tzw. nowych italianizmów, które pomimo obecności w świadomości społecznej wciąż funkcjonują jako niezasymilowane jednostki leksykalne. Co więcej, próba przekładu wielu z nich jest często niemożliwa bądź prowadzi do nieporozumień z uwagi na istnienie już utartych w obu obszarach kulturowo-językowych fałszywych konotatów bądź zapożyczeń pozornych (np. lasagne - łazanki, pasta (makaron) - pasta do smarowania, orecchiette - uszka).

Autor niniejszego artykułu podejmuje próbę, opierając się na wybranych grupach włoskich leksemów z obszaru kulinariów (podzielonych na trzy wewnętrzne kategorie tematyczne: dania i napoje, nazwy lokali gastronomicznych oraz zwyczaje kulinarne), uporządkowania wyżej opisanych tendencji oraz proponuje konkretne strategie tłumaczeniowe i lokalizacyjne mogące pomóc w unikaniu błędów w przekładzie licznych terminów bezekwiwalentowych.
\end{abstract}

Słowa kluczowe: italianizmy w polszczyźnie, leksem bezekwiwalentowy, przekład włoskich kulinaryzmów, włoskie kulturemy, zapożyczenia z języka włoskiego

\section{Wprowadzenie}

Celem podejmowanego w przedmiotowym artykule tematu, pozycjonującego go dziedzinowo między lingwistyką kulturową, socjolingwistyką a translatoryką, jest nakreślenie zjawiska znanego w językoznawstwie jako 
translation gap (dosł. luka tłumaczeniowa) w odniesieniu do terminów bezekwiwalentowych charakterystycznych dla obszaru językowego kultury wyjściowej (kulturemów), a nieobecnych w obszarze językowym kultury docelowej (w tym przypadku relacja ta dotyczyć będzie wyrażeń kulinarnych z języka włoskiego w polszczyźnie). Prezentowana analiza z pewnością nie wyczerpuje wszystkich możliwych elementów, które należałoby szerzej eksplorować pod wieloma innymi aspektami (pragmatycznym, międzykulturowym czy etymologicznym), jednak z uwagi na ograniczenia redakcyjne przedłożonego tekstu u podstaw badania stoi przede wszystkim ekspozycja jak największej liczby reprezentatywnych, a zarazem najczęściej występujących w języku polskim włoskich jednostek leksykalnych (ze szczególnym uwzględnieniem tych najnowszych, które z oczywistych względów nie są w znacznej mierze rejestrowane przez nawet najbardziej aktualne słowniki wyrazów obcych i zwrotów obcojęzycznych) oraz przedstawienia propozycji jak najskuteczniejszego i jak najwierniejszego przybliżenia ich odbiorcy polskiemu.

Intencją autora jest, aby - ze względu na wspomnianą absencję leksykograficzną wielu spośród poruszanych problemów translatorskich związanych $\mathrm{z}$ włoskimi leksemami kulinarnymi - przedkładane $\mathrm{w}$ niniejszym tekście propozycje odczytywane były z pozycji deskryptywnej, a nie stricte preskryptywnej, gdyż w niektórych przypadkach nie stanowią one jedynych możliwych sposobów wyjścia z sytuacji nieprzetłumaczalności, jak również trudno przypisywać jednostkowo komukolwiek autorstwo tych rozwiązań. $\mathrm{Z}$ tego powodu preferowaną formułą metodologiczną będzie konfrontacja różnych punktów widzenia przejawiających się w wyborach translatorskich, noszących nierzadko znamiona umowności i uznaniowości (wobec braku wiarygodnych autorytetów w źródłach pisanych), dostosowanych zarówno do właściwego kontekstu komunikacyjnego, jak i do rodzaju odbiorcy docelowego. Nie oznacza to zarazem, że niektóre z proponowanych technik lub strategii, choć niedoskonałe lub kontrowersyjne, muszą być a priori obarczone błędem, ale też nie umożliwia to stwierdzenia niedoskonałości wybranych z nich. Nim jednak dojdzie do ich zaprezentowania względem opisanych wyżej leksemów, wpierw podane zostaną podwaliny teoretyczne tego badania (kulturemy i ich status, różnice między italianizmami „starymi” i „nowymi” oraz zwięzły rys historyczny kuchni włoskiej). W końcowej części artykułu autor przedstawi swój krytyczny osąd wobec zjawiska "nowej italianizacji” polskiego nazewnictwa w obszarze handlu i usług w Polsce w XXI w. 


\section{Kulturemy jako językowe źródło wiedzy o dziedzictwie narodów i społeczeństw}

Kulturemy to jednostki języka (rozumiane jako pojedyncze słowa lub wyrażenia) nasycone treścią kulturową i osadzone w kontekście danej kultury (w tym przypadku kultury włoskiej). Są one istotne w przekładzie z uwagi na ich konotacje, ale też wysoko problematyczne ze względu na trudności w ich odtworzeniu na gruncie kultury języka docelowego (w tym przypadku języka polskiego). Alicja Nagórko definiuje kulturemy jako

ważne dla samoidentyfikacji jakiejś społeczności słowa-klucze, charakteryzujące zarówno jej stosunek do tradycji, jak i radzenie sobie z czasem teraźniejszym, aktualne przeżywanie świata (Nagórko 2004: 23-24).

Prekursorem i pionierem badań nad kulturemami jest amerykański językoznawca Peter Newmark, który w pracy A textbook of translation wyodrębnił pięć kategorii kulturowych różnicujących leksykę pod względem najważniejszych obszarów interferencji:

(1) Otoczenie: nazwy geograficzne, gatunki zwierząt i roślin, wzgórz;

(2) Kultura materialna (artefakty):
(a) żywność;
(b) ubrania;
(c) dom i miasto;
(d) transport;

(3) Kultura społeczna: praca i rozrywka;

(4) Organizacje, zwyczaje, aktywności, procedury, inne pojęcia:
(a) polityka i administracja;
(b) religia;
(c) sztuka;

(5) Gesty i zachowania ${ }^{1}$ (Newmark 1988: 95).

Jorge Diaz Cintas i Aline Remael w pracy Audiovisual Translation. Subtitling (2007: 201) rozszerzyli systematykę nakreśloną przez Newmarka, dzieląc ją zasadniczo na trzy obszary:

${ }^{1}$ Oryg.: „(1) Ecology: Flora, fauna, winds, plains, hills: (2) Material culture (artefacts); (a) Food: (b) Clothes: (c) Houses and towns; (d) Transport; (3) Social culture: work and leisure;

(4) Organisations, customs, activities, procedures, concepts; (a) Political and administrative;

(b) Religious; (c) Artistic; (5) Gestures and habits" (tlum. w artykule wykonał Ł. J. B.). 
1. Odniesienia geograficzne (elementy geografii fizycznej, obiekty geograficzne i gatunki endemiczne zwierząt i roślin);

2. Odniesienia etnograficzne (przedmioty życia codziennego, odniesienia do pracy, kultury i sztuki, narodowości i miejsca urodzenia);

3. Odniesienia społeczno-polityczne (jednostki administracji publicznej i samorządu terytorialnego, instytucji i funkcji urzędowych, życia społeczno-kulturowego i instytucji wojskowych)2.

Na gruncie przekładoznawstwa włoskiego leksemy te objęte są terminem elementi culturospecifici (elementy nacechowane kulturowo). Zdefiniowała je obszernie Irene Ranzato w pracy La traduzione audiovisiva. Analisi degli elementi culturospecifici (2010: 39): „przez elementy kulturowe - lub nacechowane kulturowo albo realia - rozumiemy te elementy obecne w ramach tekstu, który posiadają ładunek kulturowy"3. I w dalszej części dodaje:

W makrokategorii czynników kulturowych mieszczą się realia, słowa i wyrażenia, które oznaczają przedmioty nacechowanie kulturowo, to jest przedmioty materialne, które należą jedynie do określonej kultury, a które jako takie nie mają ścisłych związków z innymi językami (może najbardziej znanymi i rozpowszechnionymi są jedynie te, które oznaczają nazwy produktów żywnościowych lub typowych potraw: gastronomia jest studnią bez dna w obszarze realiów) ${ }^{4}$ (podkr. Ł. J. B.).

To ostatnie zdanie w pełni uzasadnia prowadzenie badań nad włoskimi kulturemami kulinarnymi, a w szczególności legitymizuje potrzebę pogłębienia tych poszukiwań w obrębie języka polskiego i ich właściwego przekazania i wytłumaczenia. Po lekturze słów Ranzato wydaje się to tym bardziej umotywowane, gdy pogląd taki wygłasza włoska badaczka specjalizująca się w problematyce elementów nacechowanych kulturowo.

2 Oryg.: „1. Riferimenti geografici: oggetti della geografia fisica, oggetti geografici, specie endemiche di animali e piante; 2 . Riferimenti etnografici: oggetti della vita quotidiana, riferimenti al lavoro, riferimenti ad arte e cultura, riferimenti alla nazionalità o al luogo di nascita; 3. Riferimenti sociopolitici: riferimenti a unità amministrative o territoriali, riferimenti a istituzioni o funzioni, riferimenti alla vita socioculturale”.

${ }^{3}$ Oryg.: „Per elementi culturali - o culturospecifici e realia - si intendono quegli elementi presenti all'internodi un testo che hanno un contenuto culturale".

${ }^{4}$ Oryg.: „Nella macrocategoria dei fattori culturali ricadono i realia, parole e locuzioni che indicano oggetti culturospecifici, ovvero cose materiali che appartengono solo a una determinata cultura, e che, in quanto tali, non hanno una corrispondenza precisa in altre lingue (forse i più noti e diffusi sono quelli che indicano nomi di alimenti o piatti tipici: la gastronomia è un pozzo senza fondo di realia)". 


\section{Italianizmy „stare” vs „nowe”}

Kulturowym kontaktom włosko-polskim w literaturze przedmiotu poświęcono, przynajmniej na przestrzeni ostatnich dwóch dekad, wiele pozycji naukowych i popularnonaukowych, ale kontaktom językowym (a w szczególności leksykalnym) już zdecydowanie mniej. Przywołać należy w tym kontekście choćby prace Stanisława Widłaka Italia e Polonia: popoli e lingue e contatto (2006), Marii Borejszo Zapożyczenia włoskie we współczesnej polszczyźnie (2007) czy Marka Hendrykowskiego Tutti frutti. Z dziejów kulturowych transferów języka włoskiego w polszczyźnie dawnej i współczesnej (2018). Wszystkie trzy cytowane opracowania podejmują w sposób - wydawałoby się - całościowy problematykę zapożyczeń i wpływów języka włoskiego na polszczyznę, zarówno w ujęciu synchronicznym, jak i diachronicznym (ich autorzy powołują się w tym kontekście na wspólne dzieje narodów polskiego i włoskiego: małżeństwo księżnej Bari Bony Sforzy z królem Polski Zygmuntem Starym, artystów na dworach królów Wazowskich i Stanisława Augusta Poniatowskiego, wspólne ideały i sojusze w walce o utraconą wolność w XIX w. itd.). $Z$ różnych jednak powodów autorzy zachowali wstrzemięźliwość $\mathrm{w}$ analizowaniu najnowszych włoskich leksemów w polszczyźnie, które $\mathrm{z}$ ich pozycji badawczej (w przypadku Widłaka i Borejszo, mając na uwadze czas ogłoszenia ich publikacji, wydaje się to uzasadnione) nie stanowiły ustabilizowanych jednostek leksykalnych ani tym bardziej nie były wówczas utartymi zapożyczeniami, a co najwyżej okazjonalizmami. Byłoby nieuczciwe twierdzić zatem, że świadomie nie poświęcili im dostatecznej uwagi. Faktem pozostaje, że istnieje w polszczyźnie użytkowej pokaźna grupa terminów wywodzących się z języka włoskiego, które funkcjonują od blisko dwóch dekad (a niektóre jeszcze dłużej) zarówno w dyskursie mówionym, tj. w komunikacji słownej dnia codziennego i zapośredniczonej przez komputer (computer mediated communication, CMC) przez liczne fora i komunikatory internetowe (Facebook, Instagram), w żargonie polskich italianistów, Polaków z rodzin bikulturowych, pracowników włoskich firm, urzędników placówek dyplomatycznych i osób wyjeżdżających regularnie do Włoch oraz Włochów mieszkających w Polsce, jak i pisanym (beletrystyka, książki podróżnicze i kulinarne, reklamy w prasie i w internecie, dwujęzyczne czasopisma polsko-włoskie wydawane w Polsce przez Włochów i dla Włochów, szyldy punktów usługowych, karty dań lokali gastronomicznych), które to leksemy nastręczają szeregu problemów adaptacyjnych, a niektóre z nich - mimo mozolnych prób czynionych przez użytkowników języka polskiego - pozostają nieprzetłumaczalne i zarazem mało zrozumiałe dla odbiorcy niewładającego językiem włoskim. Terminy te na- 
zywane są technicznie w literaturze przedmiotu nowymi italianizmami (Godzich 2011, Murrmann, Surmaj 2016, por. też Pinomaa 2018) dla odróżnienia ich od „starych”, występujących w języku polskim od dekad, a nawet od wieków. Należy jednak mieć na względzie, że jest to pojęcie semantycznie niestałe i nieprecyzyjne (tożsame w pewnym stopniu z makaronizmami, które oryginalnie odnoszono do obcych wtrętów z łaciny; współcześnie ich zakres pojęciowy uległ rozszerzeniu o inne języki) i zdaje się, że sami jego autorzy mają przekonanie, że posługiwać się nim należy jedynie pomocniczo z perspektywy hic et nunc. Tym bardziej że ustalenie jednoznacznej cezury czasowej dla podziału na "stare” $i$,nowe" italianizmy nie jest możliwe wprost. Byłoby zbyt proste rzec, że jest nią przełom wieków XX i XXI. Na zintensyfikowanie interferencji włoskich na polszczyznę wpływ miało bowiem szereg czynników, do których zaliczyć można, w skali makro, upadek żelaznej kurtyny (1989) i wejście Polski do Unii Europejskiej (2004), a w skali mikro wspomniane już wyżej zacieśnienie relacji gospodarczych i kulturowych między Polską a Włochami za sprawą włoskich przedsiębiorców prowadzących działalność na terenie Polski, migracji zarobkowej pracowników z Polski do Włoch i vice versa, importu włoskich towarów spożywczych i przemysłowych, polsko-włoskiej wymiany naukowej studentów, doktorantów i ludzi nauki. Pojawienie się w polszczyźnie pewnych nieznanych dotąd terminów zaczerpniętych z języka włoskiego należy traktować z ostrożnością tym bardziej, że są to terminy występujące w konkretnym kontekście kulturowym, społecznym i środowiskowym; i choć nie można ich obecności zupełnie ignorować (skoro przenikają do świadomości rodzimych użytkowników języka polskiego i w jakimś stopniu wypełniają lukę semantyczną w nazewnictwie nieznanych dotąd zjawisk kultury obcej), to jednak trudno jest $\mathrm{z}$ dzisiejszej perspektywy przewidywać, które $\mathrm{z}$ nich zadomowią się na stałe $\mathrm{w}$ języku polskim na prawach uznanych italianizmów, a które okażą się efemerydami, funkcjonującymi w przestrzeni publicznej jedynie gościnnie. Praktycznym problemem, który stanowi cel nadrzędny niniejszego tekstu, jest próba znalezienia odpowiedników czy też umożliwienia przekładu włoskich kulturemów oraz podanie konkretnych propozycji translatorskich, niezależnie od stanowisk ocennych części socjolingwistów i leksykografów co do ich przydatności i formalnej poprawności, jak również zestawienie istniejących, nierzadko spontanicznych, rozwiązań stosowanych przez użytkowników, które w mniej lub bardziej skutecznym stopniu niwelują pustkę leksykalną polszczyzny w adaptacji wybranych egzotyzmów. 


\section{3. „Kuchnia włoska” czy „kuchnie włoskie”? Krótki rys historyczny}

Kuchnia włoska należy do jednej z najbardziej popularnych na świecie. I choć termin ten pozostaje historycznie i antropologicznie niejednoznaczny (do 1861 r. nie istniało bowiem zjednoczone państwo włoskie, a upodobania żywieniowe poszczególnych ziem, które znalazły się w jego granicach, nie stanowiły monolitu, lecz konglomerat różnych składników i przepisów). Jej początki sięgają starożytności (ery etruskiej, a więc jeszcze czasów sprzed założenia Rzymu), kiedy to używano w niej trzech podstawowych składników: chleba, wina i oliwy, do dziś stanowiących podstawę większości włoskich potraw (a szerzej potraw w państwach basenu Morza Śródziemnego). Dalszy rozwój sztuki kulinarnej związany był immanentnie z ekspansją Cesarstwa Rzymskiego i wpływem nań kultury greckiej, a po jego upadku z innymi, obcymi kulturowo i kulinarnie cywilizacji łacińskiej ludami: Germanami, którzy przywieźli ze sobą mięso i słoninę, i Arabami, którzy wypiekali pitę z przyprawami, protoplastę o wiele późniejszych pizzy i focaccii. $\mathrm{W}$ okresie wielkich wypraw geograficznych i kolonizacji na Półwysep Apeniński z Nowego Świata zawitały pomidory, kukurydza, ziemniaki i papryka. Dzięki tym nowym składnikom, a w konsekwencji - nowym uprawom i smakom, kuchnia ówczesnej Italii uległa znacznemu urozmaiceniu. Główne podziały w obszarze żywienia przebiegały w dwóch osiach: pionowej - geograficznej (Północ - Południe) i poziomej - społecznej (bogaci - biedni). Podziały te utrwaliły się na tyle, że w znacznej mierze przetrwały do współczesności. Choć może wydawać się to nieprawdopodobne, ale aż do połowy XX w. Włochy zmagały się z głodem i powszechnym niedożywieniem $\mathrm{w}$ niższych warstwach społecznych, które wyeliminowano dzięki mechanicznej produkcji makaronu, uważanego dziś za chlubę i markę rozpoznawczą kuchni włoskiej na świecie, a także dzięki popularyzacji techniki wędzenia żywności dla celów konserwacji (jako odpowiedź na podwyższenie i tak drakońskiego podatku akcyzowego na sól wprowadzonego przez dyktaturę Mussoliniego, ostatecznie zniesionego dopiero w 1974 r.). Na północy Włoch jadano głównie kukurydzę i ziemniaki (stąd popularność polenty i chleba ziemniaczanego), a na południu pomidory, cebulę i bakłażany, bazę rozmaitych sosów do makaronów i pizzy. Z kolei różnice w żywieniu między poszczególnymi warstwami społeczeństwa nie miały swojej przyczyny jedynie w dostępności określonych zasobów, ale przede wszystkim uważano (począwszy od XII w.), że dobór produktów spożywczych winien być uwarunkowany pochodzeniem społecznym. I tak klasy wyższe jadały głównie ptactwo i warzywa rosnące wysoko (więc trudniejsze do zebrania), natomiast biedocie kazano zadowolić się roślinami strączkowymi i mięsem bydła z uboju oraz ry- 
bami i owocami morza (te ostatnie od zawsze były tanie i łatwe do zdobycia). Istnym paradoksem stało się, że w wyniku odwrotu od wcześniejszych wytycznych wśród arystokracji, który nastąpił dopiero w XIX w., takie dania jak pizza margherita (zawdzięczająca swoją nazwę królowej Małgorzacie), spaghetti ai frutti di mare (spaghetti $\mathrm{z}$ owocami morza) czy bistecca ai ferri (befsztyk $\mathrm{z}$ rusztu) stały się potrawami goszczącymi na stałe na salonach i w zamożnych domach włoskich.

Reasumując, bogactwo kulinarne współczesnych Włoch jest wypadkową wpływów licznych obcych kultur, które na przestrzeni blisko 3000 lat zaznaczyły swoją obecność na Półwyspie Apenińskim, tj. na długo przed etnogenezą Włochów i powstaniem zjednoczonego państwa włoskiego. Owo bogactwo manifestuje się w mnogości składników, sposobie przygotowywania dań, ale przede wszystkim w ogromnym zróżnicowaniu kuchni włoskiej pod względem geograficznym, albowiem każdy region dzisiejszej Italii serwuje własne, oryginalne potrawy, charakterystyczne jedynie dla siebie. To zróżnicowanie znajduje odzwierciedlenie także w warstwie językowej, co omówione zostanie bardziej szczegółowo w punkcie 4 .

\section{Przekład nazw kulinariów jako obszar konfrontacji kultur i wyzwań translatorskich: studium przypadku}

Zdefiniowawszy obszar badań będący przedmiotem niniejszego artykułu, jak i leżące u jego podstaw założenia teoretyczne, przybliżę następnie obraną metodologię, kryteria gromadzenia korpusu i sposobu selekcjonowania kulturemów.

Metodologia badania oparta jest na analizie jakościowej grupy leksemów wchodzących w skład obszaru semantycznego kulinariów włoskich obejmującego produkty spożywcze, potrawy i napoje (w tym desery, kawy i alkohole), lokale gastronomiczne oraz zwyczaje kulinarne praktykowane we Włoszech. Spośród blisko 300 unikalnych terminów będących kulturemami, a nie ustabilizowanymi leksykalnie zapożyczeniami (zdecydowna większość analizowanych słów lub wyrażeń nie figuruje w polskich źródłach leksykograficznych np. w Słowniku wyrazów obcych i trudnych Andrzeja Markowskiego i Radosława Pawelca), zaczerpniętych w całości z polskojęzycznych lub dwujęzycznych (polsko-włoskich) źródeł pisanych o zróżnicowanym pochodzeniu (książki kucharskie, strony internetowe z przepisami kuchennymi, przewodniki po Włoszech, karty menu restauracji z kuchnią włoską, szyldy i reklamy lokali gastronomicznych, polsko-włoskie czasopisma wydawane 
w Polsce), wyodrębniono 50 reprezentatywnych pozycji (nazwy 20 produktów spożywczych i potraw, 5 deserów, 5 napojów, 10 lokali i 10 zwyczajów kulinarnych). Następnie przypisano każdej z nich po 2-3 propozycje przekładu zaczerpnięte $\mathrm{z}$ tych samych źródeł (część $\mathrm{z}$ nich była metanarracyjnie przytoczona $\mathrm{w}$ tytule lub $\mathrm{w}$ treści danego tekstu, część stanowiła natomiast chrematonim - nazwę własną danego lokalu) lub z materiału fotograficznego zgromadzonego przez autora artykułu. Każdej propozycji przyporządkowano strategię przekładową zgodnie z repertuarem procedur stypizowanych przez Jeana-Paula Vinaya i Jeana Darbelneta (1958: 84-93), którzy wskazują na strategie bezpośrednie (tłumaczenie dosłowne, zapożyczenie, kalka) i pośrednie: transpozycję (gramatyczna zmiana kategorii przekładanego terminu), modulację (zmiana punktu widzenia w przekładanym terminie), ekwiwalencję (zastąpienie terminu jego rodzimym odpowiednikiem funkcjonalnym), naturalizację (dostosowanie brzmienia terminu do pisowni języka docelowego), objaśnienie (opis znaczenia egzotyzmu), amplifikację (rozszerzenie brzmienia terminu poprzez dodanie dodatkowego elementu), redukcję (odjęcie elementu redundantnego), substytucję (zastąpienie terminu odpowiednikiem) oraz lokalizację (tutaj: zastąpienie kulturemu źródłowego innym kulturemem, znanym użytkownikowi języka docelowego, tak aby mógł on łatwiej zrozumieć bezkwiwalentowy termin oryginalny).

\subsection{Dania i napoje}

Większość nazw produktów żywnościowych kuchni włoskiej mających w polszczyźnie leksykalnie status zapożyczeń jest przenoszona do języka polskiego bez dokonywania jakichkolwiek zmian $\mathrm{w}$ ich pisowni (spaghetti, pizza), bądź z niewielkimi zmianami wynikającymi albo z konieczności dostosowania pisowni do wymowy polskiej (parmigiano - parmezan, lasagna - lazania), albo z nieobecności w polszczyźnie znaków diakrytycznych oznaczających akcent graficzny nad samogłoskami ostatniej sylaby (ragù - ragu, tiramisù - tiramisu). Dalej idącą konsekwencją asymilacji są zniekształcenia pisowni oryginalnej mające podłoże w błędnej adaptacji leksemu oryginalnego na tle ortograficznym, np. błędna reprodukcja par spółgłoskowych (ciabatta - ciabata, pappardelle - papardelle, penne - pene), lub w ułomnej wymowie danego terminu, mającej reperkusje w pisowni (bruschetta - bruscetta, gnocch $i$ - gnocci $)^{5}$. Sednem problemu, z punktu widze-

${ }^{5}$ Dalej posuniętą konsekwencją zniekształceń pisowni względem wymowy lub vice versa 
nia przekładoznawczego, nie jest jednak to, w jaki sposób asymilowane są egzotyzmy, których znaczenie - ze względu na skalę ich popularności - jest znane użytkownikowi języka polskiego, lecz prawidłowe zrozumienie tych kulturemów, których przeciętny odbiorca polski nie jest w stanie odkryć bez znajomości języka włoskiego i z którymi w ciągu swojego życia mógł się w ogóle nie zetknąć. To właśnie tym terminom przyjrzymy się w poniższym zestawieniu, ilustrującym różne sposoby oddawania ich znaczenia w języku polskim:

Tabela 1. Zestawienie kulturemów oznaczających dania i napoje kuchni włoskiej wraz z propozycją ich tłumaczenia na język polski i nazwą strategii przekładowej

\begin{tabular}{|l|l|l|l|}
\hline Numer & \multicolumn{1}{|c|}{ Termin włoski } & Propozycja przekładu & \multicolumn{1}{|c|}{ Strategia przekładowa } \\
\hline (i) & americano & $\begin{array}{l}\text { kawa americano } \\
\text { kawa po amerykańsku } \\
\text { americana }\end{array}$ & $\begin{array}{l}\text { amplifikacja + zapożyczenie } \\
\text { transpozycja + objaśnienie } \\
\text { pseudoitalianizm }\end{array}$ \\
\hline (ii) & bombolone & $\begin{array}{l}\text { pączek bomboloni } \\
\text { pączek z dziurką }\end{array}$ & $\begin{array}{l}\text { amplifikacja + zapożyczenie } \\
\text { objaśnienie }\end{array}$ \\
\hline (iii) & bruschetta & $\begin{array}{l}\text { bruschetta } \\
\text { grzanka z pomidorami }\end{array}$ & $\begin{array}{l}\text { zapożyczenie } \\
\text { objaśnienie }\end{array}$ \\
\hline (iv) & $\begin{array}{l}\text { caffelatte / } \\
\text { caffè latte }\end{array}$ & $\begin{array}{l}\text { caffelatte / cafe latte } \\
\text { kawa z mlekiem } \\
\text { latte }\end{array}$ & $\begin{array}{l}\text { zapożyczenie } \\
\text { lokalizacja } \\
\text { redukcja }\end{array}$ \\
\hline (v) & calzone & $\begin{array}{l}\text { pizza pieróg } \\
\text { pizza nadziewana }\end{array}$ & $\begin{array}{l}\text { zapożyczenie + modulacja } \\
\text { zapożyczenie + objaśnienie }\end{array}$ \\
\hline (vi) & carpaccio & $\begin{array}{l}\text { carpaccio } \\
\text { tatar }\end{array}$ & $\begin{array}{l}\text { zapożyczenie } \\
\text { lokalizacja }\end{array}$ \\
\hline (vii) & focaccia & podpłomyk & lokalizacja \\
\hline (viii) & farfalle & $\begin{array}{l}\text { kokardki } \\
\text { motylki }\end{array}$ & $\begin{array}{l}\text { substytucja } \\
\text { tłumaczenie dosłowne }\end{array}$ \\
\hline (ix) & $\begin{array}{l}\text { formaggi e salumi } \\
\text { misti (assortiti) / } \\
\text { tagliere di formaggi } \\
\text { e salumi }\end{array}$ & deska serów i wędlin & ekwiwalencja \\
\hline (x) & frappe & $\begin{array}{l}\text { faworki } \\
\text { chrusty }\end{array}$ & $\begin{array}{l}\text { ekiwalencja } \\
\text { ekiwalencja }\end{array}$ \\
\hline
\end{tabular}

włoskich terminów kulinarnych jest promowanie - przez jednego z międzynarodowych producentów żywności mrożonej - towarów znanych na rynku polskim pod nazwami handlowymi Guseppe i Feliciana, których wymowa w reklamach telewizyjnych wskazuje na to, że winny być w rzeczywistości zapisywane odmiennie (odpowiednio: Giuseppe i Feliziana). 
Tabela 1. cd.

\begin{tabular}{|c|c|c|c|}
\hline Numer & Termin włoski & Propozycja przekładu & Strategia przekładowa \\
\hline (xi) & $\begin{array}{l}\text { frittura mista } \\
\text { (del mare) }\end{array}$ & $\begin{array}{l}\text { mix smażonych owoców } \\
\text { morza }\end{array}$ & objaśnienie \\
\hline (xii) & gnocchi & włoskie kopytka & amplifikacja + lokalizacja \\
\hline (xiii) & grappa & $\begin{array}{l}\text { włoska wódka z wino- } \\
\text { gron }\end{array}$ & objaśnienie + lokalizacja \\
\hline (xiv) & limoncello & $\begin{array}{l}\text { likier limoncello } \\
\text { włoski likier cytrynowy } \\
\text { włoska cytrynówka }\end{array}$ & $\begin{array}{l}\text { amplifikacja + zapożyczenie } \\
\text { objaśnienie } \\
\text { amplifikacja + lokalizacja }\end{array}$ \\
\hline (xv) & macedonia & $\begin{array}{l}\text { sałatka macedońska } \\
\text { sałatka owocowa }\end{array}$ & $\begin{array}{l}\text { amplifikacja + transpozycja } \\
\text { ekwiwalencja }\end{array}$ \\
\hline (xvi) & orecchiette & $\begin{array}{l}\text { muszelki } \\
\text { uszka }\end{array}$ & $\begin{array}{l}\text { substytucja } \\
\text { tłumaczenie dosłowne }\end{array}$ \\
\hline (xvii) & panettone & $\begin{array}{l}\text { ciasto panettone } \\
\text { włoska babka bożonaro- } \\
\text { dzeniowa }\end{array}$ & $\begin{array}{l}\text { amplifikacja + zapożyczenie } \\
\text { objaśnienie }\end{array}$ \\
\hline (xviii) & panino & $\begin{array}{l}\text { kanapka panini } \\
\text { kanapka na ciepło/gril- } \\
\text { lowana }\end{array}$ & $\begin{array}{l}\text { amplifikacja + zapożyczenie } \\
\text { objaśnienie }\end{array}$ \\
\hline (xix) & pannacotta & $\begin{array}{l}\text { włoski budyń } \\
\text { deser pana kota }\end{array}$ & $\begin{array}{l}\text { objaśnienie } \\
\text { amplifikacja + naturalizacja }\end{array}$ \\
\hline$(\mathrm{xx})$ & pasta al dente & $\begin{array}{l}\text { nierozgotowany ma- } \\
\text { karon }\end{array}$ & objaśnienie \\
\hline (xxi) & $\begin{array}{l}\text { pizza rossa } \\
\text { pizza bianca }\end{array}$ & $\begin{array}{l}\text { pizza } \mathrm{z} \text { sosem pomido- } \\
\text { rowym } \\
\text { pizza bez sosu pomido- } \\
\text { rowego }\end{array}$ & $\begin{array}{l}\text { zapożyczenie + objaśnienie } \\
\text { zapożyczenie + objaśnienie }\end{array}$ \\
\hline (xxii) & prosciutto crudo & $\begin{array}{l}\text { szynka parmeńska } \\
\text { szynka prosciutto } \\
\text { szynka dojrzewająca }\end{array}$ & $\begin{array}{l}\text { pseudoitalianizm } \\
\text { amplifikacja + zapożyczenie } \\
\text { ekwiwalencja + objaśnienie }\end{array}$ \\
\hline (xxiii) & radicchio & $\begin{array}{l}\text { sałata radicchio } \\
\text { sałata na gorzko } \\
\text { cykoria włoska }\end{array}$ & $\begin{array}{l}\text { amplifikacja + zapożyczenie } \\
\text { objaśnienie } \\
\text { substytucja + amplifikacja }\end{array}$ \\
\hline (xxiv) & (sugo al) ragù & $\begin{array}{l}\text { sos pomidorowy z mię- } \\
\text { sem mielonym } \\
\text { sos boloński }\end{array}$ & $\begin{array}{l}\text { objaśnienie } \\
\text { pseudoitalianizm }\end{array}$ \\
\hline$(\mathrm{xxv})$ & ravioli & włoskie pierożki & amplifikacja + lokalizacja \\
\hline (xxvi) & ricotta & ser ricotta & amplifikacja + zapożyczenie \\
\hline (xxvii) & stuzzichini & słone przekąski & substytucja \\
\hline (xxviii) & tortellini & $\begin{array}{l}\text { włoskie uszka } \\
\text { pierożki faszerowane }\end{array}$ & $\begin{array}{l}\text { amplifikacja + lokalizacja } \\
\text { lokalizacja + objaśnienie }\end{array}$ \\
\hline
\end{tabular}


Tabela 1. cd.

\begin{tabular}{|c|c|c|c|}
\hline Numer & Termin włoski & Propozycja przekładu & Strategia przekładowa \\
\hline (xxix) & tramezzino & $\begin{array}{l}\text { tost } \\
\text { trójkątna kanapka } \\
\text { na pieczywie tostowym }\end{array}$ & $\begin{array}{l}\text { substytucja (przez egzotyzm } \\
\text { z języka C) } \\
\text { objaśnienie }\end{array}$ \\
\hline$(\mathrm{xxx})$ & vino della casa & $\begin{array}{l}\text { wino domowe } \\
\text { wino domu }\end{array}$ & $\begin{array}{l}\text { substytucja } \\
\text { tłumaczenie dosłowne }\end{array}$ \\
\hline
\end{tabular}

Z powyższego repertorium kulturemów, bardzo zróżnicowanych pod względem rodzajowym (dania ciepłe/zimne, potrawy słone/słodkie, przekąski/dania główne, napoje ciepłe/zimne, alkoholowe/bezalkoholowe), jak i formalno-językowym (nazwy pospolite i własne, chrematonimy/eponimy, frazeologizmy, zgrubienia/zdrobnienia), wyłania się całościowy i uporządkowany obraz konsekwentnie manifestujących się tendencji, które można sprowadzić do następujących wyznaczników:

A. Leksemy o większym ładunku obcości dla użytkowników polskiego poprzedzane są określnikiem rodzajowym: kawa americano, pączek bomboloni, kawa latte, ciasto panettone, kanapka panini (l.mn. od wł. panino), szynka prosciutto, sałata radicchio, ser ricotta itd. Zabieg ten jest zrozumiały i z pewnością ułatwia poznanie znaczenia terminu oryginalnego odbiorcy niewładającemu językiem włoskim. Jednocześnie jednak prowadzi do powstawania form redundantnych (w przypadku panini, prosciutto, radicchio i ricotta jest to ewidentne), w istocie tautologicznych nazw porównywalnych do tworów czasów PRL-u takich jak serek fromage czy Siostry Sisters z Kabaretu Olgi Lipińskiej. Redukcja caffelatte do latte z pominięciem określnika rodzajowego kawa czyni z napoju kawowego jedynie szklankę mleka. Z kolei wyrażenie deser pana kota (ze spolszczoną ortografią i rezygnacją z podwójnych spółgłosek) daje fantazyjne wrażenie, jakoby producentem bądź pomysłodawcą tego produktu było zwierzę, co zostało skomentowane przez internautów za pomocą odpowiednich memów i innych prześmiewczych grafik (por. rys. 2). Można oczekiwać, że wraz z popularyzacją powyższych produktów żywnościowych w kolejnych latach potrzeba tak dokładnego ich dookreślania zwyczajnie ustanie, jak miało to miejsce choćby w przypadku mozzarelli, która w przepisach i kartach dań pojawia się od jakiegoś czasu już samodzielnie np. sałatka $z$ mozzarella zamiast onegdaj stosowanego dookreślenia sałatka $z$ serem mozzarella. 


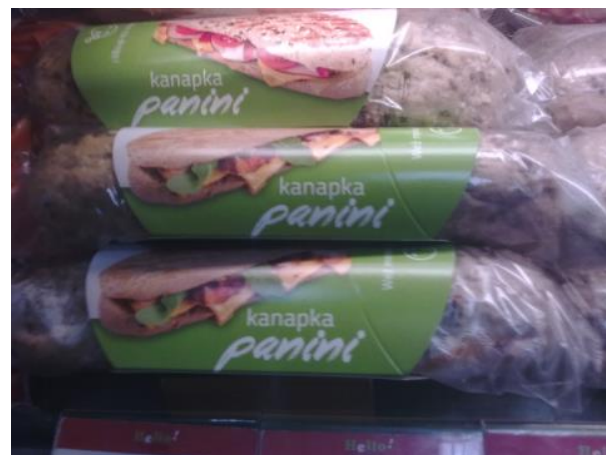

Rys. 1. Kanapka panini (zdjęcie autora artykułu)

B. Leksemy oznaczające włoskie dania i produkty, których pewne cechy dystynktywne są przypadkowo zbieżne z daniami i produktami kuchni polskiej, w przekładzie na język polski zazwyczaj ulegają daleko posuniętej domestykacji ${ }^{6}$ poprzez objaśnienie (które formalnie nie budzi większych wątpliwości) lub zastąpienie polskim terminem lokalizującym poszerzonym o przymiotnik oznaczający kraj pochodzenia (w tym przypadku Włochy), np. gnocchi - włoskie kopytka, grappa - włoska wódka z winogron, limoncello - włoska cytrynówka, panettone - włoska babka, pannacotta - włoski budyń, radicchio - cykoria włoska, ravioli - włoskie pierożki, tortellini - włoskie uszka. W odniesieniu do dań makaronowych ta ostatnia procedura wydaje się uzasadniona, jeśli objaśnieniu w cudzysłowie towarzyszy nazwa oryginalna (przy tej okazji warto zwrócić uwagę na niezbyt trafne dosłowne tłumaczenie orecchiette na uszka lansowane przez niektórych producentów makaronów w Polsce, gdyż te mają de facto kształt muszelek, tymczasem więcej podobieństw fizycznych polskich uszek można upatrywać we włoskich tortellini, przez niektórych nazywanych omyłkowo pierożkami). Kwestia ta jest jeszcze bardziej skomplikowana w przypadku alkoholi (grappa nie może być wódką, gdyż ta ostatnia produkowana jest ze zbóż lub ziemniaków, a nie owoców, co również ma swoje umocowania prawne) czy deserów (panna cotta powstaje z gotowanej śmietanki z żelatyną, a budyń z ubitych jaj z cukrem lub masłem).

${ }^{6}$ Za L. Venutim (1995): egzotyzacja (foreignization) i udomowienie (domestication). 


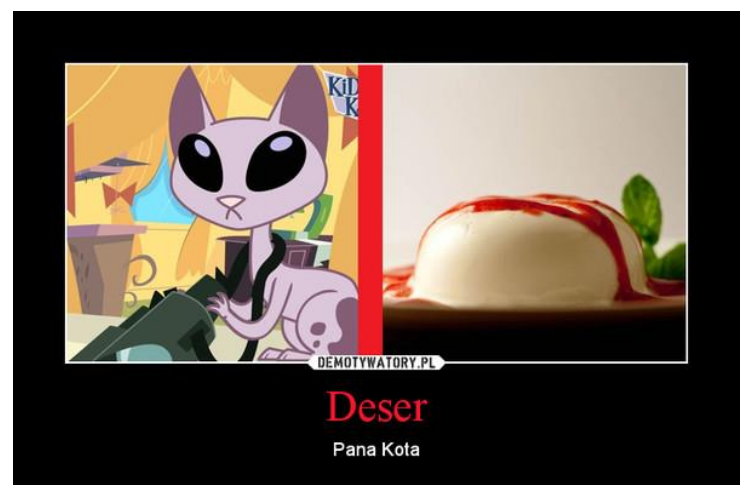

Rys. 2. Deser Pana Kota (źródło: demotywatory.pl)

C. Leksemy oznaczające dania i produkty kuchni włoskiej, które stają się coraz bardziej rozpoznawalne na gruncie polskim, takie jak focaccia (podpłomyk) czy carpaccio (tatar), wbrew wszelkim zastrzeżeniom nie wymagają nadmiernego udomowienia w polszczyźnie. W szczególności warto odnotować, że termin carpaccio (będący eponimem pochodzącym od nazwiska weneckiego malarza Vittore Carpaccio, z którego obrazami miał być kojarzony wygląd tego dania), choć z tatarem łączy go wspólny element - bardzo cienko krojone surowe mięso ( $w$ wydaniu włoskim podawane dodatkowo z płatkami parmezanu i oliwą) - został chętnie zagospodarowany przez kuchnię wegan i wegetarian, którzy na jego kanwie stworzyli własne dania jak np. carpaccio $z$ buraka (adoptujące się o wiele zgrabniej niż tatar z buraka, kojarzony w tradycyjnej kuchni polskiej jako danie mięsne).

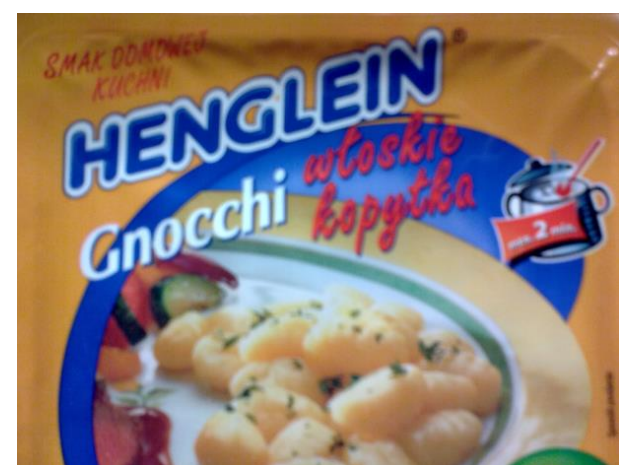

Rys. 3. Gnocchi - włoskie kopytka (źródło: ceneo.pl) 
D. Leksemy posiadające odpowiedniki funkcjonalne, które w przekładzie można stosować wprost, takie jak bomboloni (l.mn. od wł. bombolone) - pączki, frappe - faworki, macedonia - sałatka owocowa, nie wymagają akcentowania w żaden sposób ich obcego pochodzenia, szczególnie gdy są produkowane i sprzedawane poza Włochami. Formy te wprowadzają konsumenta w błąd, jakoby były produktami importowanymi (paczek bomboloni znajdował się onegdaj w ofercie jednej z dużych polskich sieci piekarń - vide rys. 4, a sałatka macedońska - sieci sklepów sprzedających gotowe dania pudełkowe), podczas gdy z językowego punktu widzenia terminy te są „zapożyczeniami luksusowymi” (wł. prestiti di lusso), funkcjonalnie zbędnymi, których używanie może być postrzegane jako „wyraz snobizmu” (Markowski, Pawelec 2004: 122).

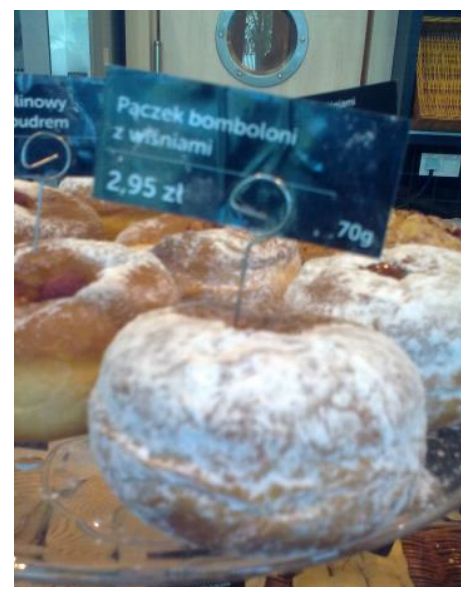

Rys. 4. Pączek bomboloni (zdjęcie autora artykułu)

E. Osobną grupę stanowią wyrażenia, które choć przetłumaczone, zadomowiły się już w języku polskim i kojarzone są z kuchnią włoską, to w rzeczywistości pozostają pseudoitalianizmami i nie wykazują ciągłości ze źródłosłowem oryginalnym, np. ragù - sos boloński, prosciutto crudo - szynka parmeńska (ten ostatni jest towarem prawnie chronionym $\mathrm{DOP}^{7}$ i nie może być nazywany nazwą geograficzną, jeśli nie jest produkowany w obszarze swojego pochodzenia). W podobnym duchu odbierane są przez rodowitych Włochów nieuwzględnione w powyższej klasyfikacji kiełbasa peperoni (wł. peperone oznacza 'paprykę,' jest to leksem zapośredniczony przez język

7 Denominazione di Origine Protetta - chroniona nazwa pochodzenia. 
angielski) oraz pizza neapolitańska podawana na całym świecie z rybą (oryginalna pizza margherita wypiekana w Neapolu, składa się tylko z pomidorów, mozzarelli i bazylii).

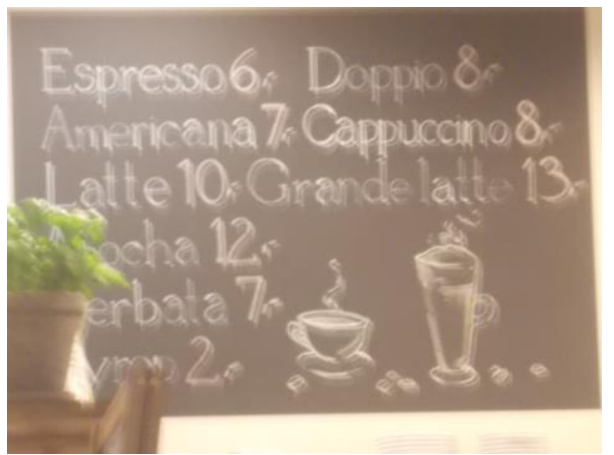

Rys. 5. Kawa americana i latte w menu kawiarni (zdjęcie autora artykułu)

\subsection{Lokale gastronomiczne}

W kolejnej części analizy przyjrzymy się lokalom gastronomicznym oferującym dania kuchni włoskiej. Ich zróżnicowanie wynika zarówno ze sposobu podawania posiłków, czy to z obsługą kelnerską (ristorante, trattoria, pizzeria) lub bez (bar, paninoteca, tavola calda), jak i wysokości cen (do tańszych należą tavola calda i osteria, do droższych - ristorante i enoteca). Różne są też godziny ich otwarcia oraz wybór dań (ristoranti czynne są co do zasady w porze obiadu, jak i kolacji, i oferują pełny asortyment, podczas gdy tavola calda i osterie otwierane są domyślnie w godzinach obiadu i proponują skromniejszy, kilkudaniowy jadłospis).

Tabela 2. Zestawienie kulturemów oznaczających włoskie lokale gastronomiczne wraz z propozycją ich tłumaczenia na język polski i nazwą strategii przekładowej

\begin{tabular}{|l|l|l|l|}
\hline Numer & \multicolumn{1}{|c|}{ Termin włoski } & Propozycja przekładu & \multicolumn{1}{|c|}{ Strategia przekładowa } \\
\hline (xxxi) & bar & $\begin{array}{l}\text { bar } \\
\text { kawiarnia }\end{array}$ & $\begin{array}{l}\text { zapożyczenie } \\
\text { ekwiwalencja }\end{array}$ \\
\hline (xxxii) & bufet & $\begin{array}{l}\text { restauracja samoobsłu- } \\
\text { gowa } \\
\text { bufet/stół szwedzki }\end{array}$ & ekwiwalencja \\
amplifikacja \\
\hline
\end{tabular}


Tabela 2. cd.

\begin{tabular}{|l|l|l|l|}
\hline Numer & \multicolumn{1}{|c|}{ Termin włoski } & \multicolumn{1}{|c|}{ Propozycja przekładu } & \multicolumn{1}{|c|}{ Strategia przekładowa } \\
\hline (xxxiii) & enoteca & $\begin{array}{l}\text { vinoteca/winoteka } \\
\text { winiarnia }\end{array}$ & $\begin{array}{l}\text { naturalizacja } \\
\text { substytucja }\end{array}$ \\
\hline (xxxiv) & osteria & $\begin{array}{l}\text { jadłodajnia } \\
\text { karczma/oberża }\end{array}$ & $\begin{array}{l}\text { substytucja } \\
\text { lokalizacja }\end{array}$ \\
\hline$($ xxxv) & paninoteca & $\begin{array}{l}\text { bar kanapkowy } \\
\text { sandwiczernia }\end{array}$ & $\begin{array}{l}\text { substytucja } \\
\text { naturalizacja (z elementem } \\
\text { egzotyzacji przez ang. sand- } \\
\text { wich) }\end{array}$ \\
\hline$($ xxxvi) & pizzeria & $\begin{array}{l}\text { pizzeria } \\
\text { pizzernia }\end{array}$ & $\begin{array}{l}\text { zapożyczenie } \\
\text { naturalizacja }\end{array}$ \\
\hline$($ xxxvii) & ristorante & restauracja & substytucja \\
\hline$(x x x v i i i)$ & spaghetteria & spageciarnia & naturalizacja \\
\hline$($ xxxix) & tavola calda & $\begin{array}{l}\text { bar z gorącymi daniami } \\
\text { bar mleczny }\end{array}$ & $\begin{array}{l}\text { objaśnienie } \\
\text { lokalizacja }\end{array}$ \\
\hline$(x l)$ & trattoria & $\begin{array}{l}\text { trattoria } \\
\text { gospoda }\end{array}$ & $\begin{array}{l}\text { zapożyczenie } \\
\text { lokalizacja }\end{array}$ \\
\hline
\end{tabular}

Niewątpliwie lokale takie jak ristorante, pizzeria i trattoria poza intuicyjną możliwością wydedukowania przez polskiego odbiorcę, że świadczą usługi gastronomiczne, są też coraz bardziej popularnymi chrematonimami, stanowią bowiem części składowe nazw przedsiębiorców, uzupełnionych nierzadko o toponimy kojarzone z Włochami (np. na gastronomicznej mapie Warszawy można odnotować takie pozycje jak Ristorante Venezia, Pizzeria Capri, Trattoria Italia). Coraz większą popularnością cieszą się też, szczególnie w dużych miastach Polski, miejsca podające wino wraz z przystawkami w postaci serów, wędlin, warzyw itd., które we Włoszech znane są jako enoteche (polska winoteka, w wersji pseudoitalianizowanej vinoteca, nie ma żadnego związku z językiem włoskim, gdzie dla tego typu działalności preferowany jest prefiks starogrecki oıvó - eco, oznaczający (wino'). Paradoksalnie największe rozbieżności semantyczne zaobserwować można w obecnych w języku włoskim, jak i polskim, internacjonalizmach bar i buffet. Ten pierwszy, wywodzący się z języka angielskiego (gdzie w swoim prymarnym znaczeniu odnosi się do miejsca, gdzie podawane są napoje, głównie alkoholowe), w języku włoskim jest de facto formą kawiarni, poszerzoną o drobne usługi gastronomiczne (kanapki, rogaliki, słodycze) i napoje zimne, odwiedzaną przez Włochów głównie rano przed pracą lub w ciągu dnia w celu spożycia szybkiej przekąski. Tymczasem w tradycji polskiej bar (poza zbieżnością semantyczną z pierwowzorem angielskim) denotuje również lokal gastronomiczny $\mathrm{z}$ daniami gotowymi typu fast food (zapiekanka, hamburger, 
hot dog), nie ma zatem wielu punktów stycznych z włoskim barem. Do przełożenia włoskiego buffet konieczne jest rozszerzenie jego polskiego brzmienia o przymiotnik szwedzki (równolegle do stołu szwedzkiego) lub samoobsługowy (tradycję tego typu formy gastronomii wprowadziła do Polski w latach 90. XX w. duża sieć sklepów meblowych ze Szwecji), gdyż w polskim bufecie, będącym w niektórych zakładach pracy często odpowiednikiem sklepiku szkolnego, sprzedawane są, poza produktami wysoko przetworzonymi, co najwyżej kanapki, sałatki i inne gotowe dania podawane na zimno (raczej nie dania stricte obiadowe, które klient nakładałby na talerz samodzielnie). Ciekawą językowo próbą naturalizacji włoskich pizzeria, spaghetteria i paninoteca są odpowiednio pizzernia, spageciarnia i sandwiczernia (ta ostatnia propozycja, będąca w istocie pseudoanglicyzmem, dużo częściej bywa zastępowana przez rodzimy bar kanapkowy, choć jako forma użytkowa pojawia się nawet w podręcznikach wydawanych przez polonistów, vide Kłosińska 2014: 259-265). Włoskie egzotyzmy pizzeria, spaghetteria i trattoria funkcjonują w świadomości polskiego odbiorcy, jednak z minimalnie zniekształconą względem włoskiego oryginału wymową: [pit'tserja], [spaget'terja] i [trat'torja]. Na marginesie warto dodać, że w przypadku pizzerii mamy też do czynienia $z$ innymi pochodnymi neoformacjami, niewymienionymi w powyższej tabeli, jak np. pizzaiolo (osoba wypiekająca pizzę) - pizzer, pizzetta (mała pizza, jedzona na zimno) - pizzerina lub pizzerka. Ostatnią kategorię lokali stanowią osteria i tavola calda. Popularne szczególnie na południu Włoch, serwują skromne dania i po niewygórowanych cenach. Jako ich odpowiedniki funkcjonalne mogą być kojarzone w polskich warunkach odpowiednio jadłodajnia i bar mleczny (ta ostatnia propozycja jest szczególnie wskazywana jako locale przez odwiedzających Polskę Włochów, odrzucających włoski fałszywy konotat latteria, który jest w rzeczywistości sklepem z nabiałem, a nie lokalem gastronomicznym, wbrew wskazaniom niektórych źródeł leksykograficznych wydawanych w Polsce).

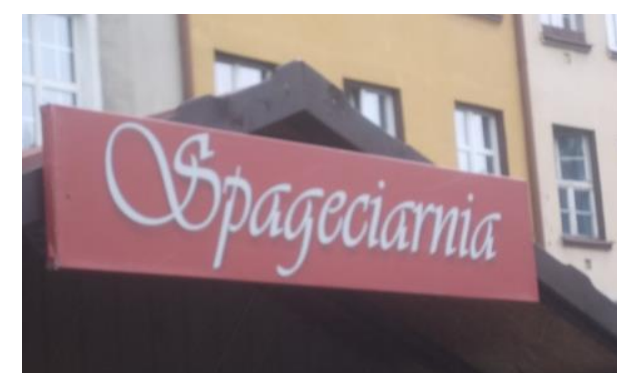

Rys. 6. Lokal gastronomiczny „Spageciarnia” (zdjęcie autora artykułu) 


\subsection{Zwyczaje kulinarne}

Trzeci, ostatni obszar badania poświęcony jest zwyczajom kulinarnym współczesnych Włoch. Stanowi on tę sferę życia społecznego, która z oczywistych względów charakteryzuje się wyraźnym ładunkiem kulturowym, a co za tym idzie - utrudnioną przekładalnością jego terminów. Antycypując treść poniższego zestawienia, można $\mathrm{z}$ całą mocą stwierdzić, że dominującą procedurą będzie w tym kontekście strategia objaśnienia (znajdująca zastosowanie dla aż $8 \mathrm{z} 10$ analizowanych kulturemów).

Tabela 3. Zestawienie kulturemów oznaczających włoskie zwyczaje kulinarne wraz z propozycją ich tłumaczenia na język polski i nazwą strategii przekładowej

\begin{tabular}{|l|l|l|l|}
\hline Numer & \multicolumn{1}{|c|}{ Termin włoski } & Propozycja przekładu & \multicolumn{1}{|c|}{ Strategia przekładowa } \\
\hline (xli) & antipasto & $\begin{array}{l}\text { przystawka (jedzona } \\
\text { przed głównymi dania- } \\
\text { mi obiadu) }\end{array}$ & ekwiwalencja + objaśnienie \\
\hline (xlii) & aperitivo & $\begin{array}{l}\text { przekąska przed kolacją } \\
\text { (spożywana na zaostrze- } \\
\text { nie apetytu) } \\
\text { aperitif }\end{array}$ & objaśnienie \\
\hline (xliii) & contorno & $\begin{array}{l}\text { jarzyny (dodatek do } \\
\text { drugiego dania) }\end{array}$ & fałszywy konotat \\
\hline (xliv) & coperto & $\begin{array}{l}\text { opłata za nakrycie do } \\
\text { stołu w lokalu }\end{array}$ & objaśnienie \\
\hline (xlv) & digestivo & $\begin{array}{l}\text { mocny alkohol pity po } \\
\text { posiłku } \\
\text { poganiacz }\end{array}$ & objaśnienienie \\
\hline (xlvi) & fare alla romana & $\begin{array}{l}\text { sposób płatności za ra- } \\
\text { chunek z podziałem na } \\
\text { liczbę osób siedzących } \\
\text { przy jednym stole }\end{array}$ & objaśnienie \\
\hline substytucja (przez kalkę \\
\hline z jęzka C)
\end{tabular}


Rozważając powyższe propozycje przekładowe, należy zwrócić uwagę na to, że niektóre z zachowań włoskich są w pewnej mierze zbliżone do zwyczajów polskich. O ile polski obiad - w przeciwieństwie do włoskiego - składa się zwykle z 3, a nie 5 dań (w Polsce nie jada się przystawki na początek antipasto, podczas gdy jarzyny - contorno, są częścią głównego dania, a nie autonomicznym dodatkiem), o tyle jako danie główne podawane jest mięso z dodatkami (ziemniakami, ryżem). Różni się za to zawartość pierwszego dania (w Polsce - zupa, we Włoszech - makaron), które Włosi w pewnych okolicznościach zwykli pomijać (saltare il primo). Również na podwieczorek (merenda), jadany głównie przez dzieci, podaje się słodycze lub owoce. Rytuał wycierania talerza chlebem (fare la scarpetta) jest we Włoszech postawą akceptowalną społecznie, natomiast w Polsce - czyniony publicznie stoi w sprzeczności z savoir vivréem przy stole, stąd brak potrzeby osobnego nazywania tego zjawiska w polszczyźnie. We Włoszech praktykuje się też digestivo (wypicie małej ilości mocnego alkoholu, głównie na bazie ziół, na wspomożenie trawienia po obiedzie; jest to rytuał podobny do angielskiego chaser, który umownie tłumaczy się jako poganiacz). Rozbieżności wywołują z kolei kwestie dotyczące płatności: w Polsce nie płaci się przecież za fakt zjedzenia posiłku sztućcami na talerzu w lokalu (coperto), co dla Włocha bywa niezrozumiałe; opłata za obsługę (servizio) jest zazwyczaj obowiązkowa (w Polsce jedynie dla rezerwacji grupowych), a propozycja podziału rachunku arytmetycznie przez liczbę osób siedzących przy stole (fare alla romana) u osoby, która zjadła najmniej lub wybrała najtańszą potrawę z karty, może pozostawiać dyskomfort psychiczny. We Włoszech praktykowane są również dwie formy posiłków, które nie znajdują bezpośredniego odpowiednika na gruncie polskim: aperitivo (jadane jako przekąska przed kolacją z kieliszkiem wina lub wermutu na zaostrzenie apetytu) oraz rinfresco (forma poczęstunku praktykowana podczas wydarzeń odbywających się poza porą obiadu lub kolacji). W pierwszym przypadku za błąd tłumaczeniowy uważa się zastosowanie fałszywego odpowiednika aperitif, który bardziej odnosi się do spożywanego napoju, a nie konsumpcji towarzyszących mu przekąsek, za które klient dodatkowo nie płaci; $w$ drugim przypadku widać pewną zbieżność $\mathrm{z}$ funkcjonującym $\mathrm{w}$ języku polskim anglicyzmem catering, przy czym we Włoszech kanapki i słodycze zastępowane są przez słone przekąski kryjące się pod zbiorczym terminem stuzzichini (od wł. stuzzicare 'podsycać, pobudzać) w postaci zawijanych słonych ciast, tart, paluszków i oliwek. 


\section{Zakończenie}

Włoski obszar kulinariów charakteryzuje się pokaźnym dziedzictwem kulturowym, będącym konsekwencją trzech tysiącleci obecności i wpływów rozmaitych obcych ludów na Półwyspie Apenińskim. Stąd też zrozumiałe jest, jak bogata musi być spuścizna językowa w tym polu leksykalnym. Kuchnia współczesnych Włoch należy bowiem do jednych $\mathrm{z}$ najbardziej popularnych i uznanych na świecie. Jej daleko posunięta internacjonalizacja, mająca swoje korzenie w emigracji zarobkowej Włochów do Stanów Zjednoczonych w II połowie XIX w. i w I połowie XX w., ale także w przemyślanej i rozważnej polityce promocyjnej Włoch na świecie w II połowie XX w. (fenomen made in Italy), włoskich marek eksportowych (domy mody, producenci kosmetyków i perfum, samochodów, sprzętu elektronicznego itd.), wpływie pop kultury (filmy Felliniego i Antonioniego, festiwale w Wenecji i San Remo) spowodowały, że również włoskie produkty żywnościowe takie jak makarony, wędliny, sery i wina stały się nie tylko rozpoznawalne, ale i pożądane w Europie i poza nią. Skutkiem ubocznym tak szeroko zakrojonej globalizacji stały się liczne fałszerstwa i podróbki włoskiej żywności, podszywanie się małych, nieznanych zagranicznych producentów pod znane i cenione włoskie marki i imitowanie przez nie popularnych wytworów włoskiej kuchni, co w dłuższej perspektywie spowodowało powstanie nieznanych we Włoszech towarów takich jak kiełbasa peperoni, spaghetti bolognese, pizza neapolitana, pizzaburger, ser capresi i wiele innych. Dopiero w $2008 \mathrm{r}$. rząd włoski powołał do życia Agenzia Nazionale per la Sicurezza Alimentare (Narodową Agencję Bezpieczeństwa Żywności) afiliowaną przy Ministerstwie Zdrowia, której zadaniem statutowym jest między innymi śledzenie naruszeń w postaci podrabiania włoskich produktów spożywczych za granicą.

Powracając do kwestii przekładoznawczych, obecność włoskich kulturemów kulinarnych na gruncie języka polskiego manifestuje się w dwojaki sposób: z jednej strony mamy do czynienia ze starymi, dobrze zasymilowanymi italianizmami takimi jak pizza, spaghetti, lasagne itd., które funkcjonują w polszczyźnie od wielu dekad. Z drugiej strony przemiany społeczne, przejawiające się w stylu życia Polaków, spędzaniu wolnego czasu przez nich na posiłkach poza domem oraz rosnący dobrostan klasy średniej niższej i średniej właściwej (przynajmniej wśród mieszkańców średnich i dużych miast) powodują, że wzrasta zainteresowanie i fascynacja obcą kulturą, do których zalicza się również kultura kulinarna współczesnych Włoch. Stąd coraz więcej produktów importowanych z Włoch i lokali serwujących włoską kuchnię (nierzadko prowadzonych przez rodowitych Włochów). To wszystko powoduje, że interferencje i kontakty językowo-kulturowe następują w sposób 
oddolny, z pominięciem jakichkolwiek czynników weryfikacyjnych (nazwy usług, towarów, lokali i punktów sprzedaży narzucają ich właściciele, a popularyzują je w świadomości społecznej klienci). Tzw. nowe italianizmy wnikają do języka polskiego bez zachowania łączności i tradycji ze starymi (np. szynka prosciutto jest tworem późniejszym niż szynka parmeńska lub szynka dojrzewająca). Przy tak posuniętej komercjalizacji języka, dołączając do tego wszechobecne wpływy języka angielskiego, można prognozować, że w ciągu kilku lat takie wyrażenia jak prosecco party, serata aperitivo czy apericena wejdą na stałe przynajmniej do języka mówionego młodego i średniego pokolenia Polaków, bez żadnej możliwości oceny ich użyteczności i niezbędności, nie mówiąc już o potrzebie poprawnego przekładu.

Omówione w części właściwej badania przykłady tej „nowej italianizacji” nazewnictwa polskiego w obszarze handlu i usług w XXI w. (ze szczególnym uwzględnieniem branży restauracyjnej i spożywczej) są zaledwie przyczynkiem do tego, jakie wyzwania stoją przed tłumaczami języka włoskiego $\mathrm{w}$ jeszcze bardziej wiernym i precyzyjnym przybliżeniu odbiorcy polskiemu faktycznego znaczenia włoskich kulturemów kulinarnych, tak dowolnie interpretowanych i z trudnością asymilowanych, co usiłowano jedynie przekrojowo nakreślić w niniejszym artykule.

\section{Źródła}

https://www.ceneo.pl/61827719 (ostatni dostęp: 14.07.2019)

https://demotywatory.pl/4087648 (ostatni dostęp: 14.07.2019)

http://www.gazzettaitalia.pl/ (ostatni dostęp: 14.07.2019)

https://www.kwestiasmaku.com (ostatni dostęp: 14.07.2019)

https://kuchnialidla.pl/przepisy/kuchnia-wloska (ostatni dostęp: 14.07.2019) http://www.wlochysubiektywnie.pl/historia-wloskich-zwyczajow-kulinarnych/ (ostatni dostęp: 14.07.2019)

http://www.wlochysubiektywnie.pl/najslynniejsza-wloska-ksiazka-kulinarna/ (ostatni dostęp: 14.07.2019)

\section{Literatura}

Borejszo M., 2007, Zapożyczenia włoskie we współczesnej polszczyźnie, Poznań.

Diaz Cintas J., Remael A., 2007, Audiovisual translation. Subtitling, Manchester. 
Godzich A., 2011, Wybrane nowe italianizmy we współczesnej polszczyźnie, „Kwartalnik Językoznawczy”, 3(7), s. 46-65.

Hendrykowski M., 2018, Tutti frutti. Z dziejów kulturowych transferów języka włoskiego w polszczyźnie dawnej i współczesnej, Poznań.

Kłosińska K. (red.), 2014, Formy i normy, czyli poprawna polszczyzna w praktyce, wyd. popr., Warszawa.

Markowski A., Pawelec R., 2004, Słownik wyrazów obcych i trudnych, Warszawa.

Murrmann J., Surmaj P., 2016, La peculiarità del linguaggio giornalistico sportivo in base all'analisi degli articoli della Gazzetta dello Sport, Wrocław.

Nagórko A., 2004, Metody konfrontatywne a etnolingwistyka (lingwistyka kulturowa), [w:] Multikulturalitás, nemzeti identitás, kisebbeségek Magyarországon és Lengyelországban. Nylev - irodalom - kultúra, E. Fórián (red.), Debrecen, s. 23-33.

Newmark P., 1988, A textbook of translation, New York.

Pinomaa O., 2018, Gli italianismi nella lingua speciale della gastronomia: uno studio su libri di cucina pubblicati in finlandese tra il 1997 e il 2016, Turku.

Ranzato I., 2010, La traduzione audiovisiva, Analisi degli elementi culturospecifici, Roma.

Venuti L., 1995, The translator's invisibility. A history of translation, London. Vinay J.-P., Darbelnet J., 1958/2000, A methodology for translation, tłum. i red. J. C. Sager, M.-J. Hamel, Amsterdam (1. wyd.: Stylistique comparée du français et de l'anglais. Méthode de traduction, [w:] The translation studies reader, L. Venuti (red.), London 1958, s. 84-93).

Widłak S., 2006, Italia e Polonia. Popoli e lingue e contatto, Kraków.

\section{Difficulties in the translation of Italian non-equivalent lexemes - the example of Italian culinary terminology}

\section{Summary}

The terminological abundance of the Italian language in the most popular areas of life (cuisine, fashion, music, etc.) as well as intensified Polish-Italian relationships of the late $20^{\text {th }}$ century and the early $21^{\text {st }}$ century in particular are the causes of the emergence of the so-called new Italianisms in the Polish language that are still perceived as unassimilated lexical units despite their widespread presence in social awareness. What is more, an attempt to translate some of them appears to be unworkable or leads 
to several misunderstandings due to the existence of false connotations or apparent borrowings which are well rooted in both Polish and Italian languages and their cultural areas (e.g. IT lasagne - PL łazanki, IT pasta (makaron) - PL pasta do smarowania, IT orecchiette - PL uszka etc.).

The author of the present paper attempts to put into order the above-mentioned tendencies based on the selected groups of Italian lexemes belonging to the cuisinerelated area (divided into three topic categories such as food and drinks, venues and culinary habits) as well as to suggest determined translation and location strategies ready to be applied to avoid mistakes in the translation process of several non-equivalent Italian terms.

Keywords: Italian cuisine translation, Italian borrowings, Italian culture-specific terms, Italianisms in Polish language, non-equivalent lexemes

\section{(c) $\bigodot_{\mathrm{BY}} \bigodot_{\mathrm{ND}}$}

